\title{
Pola Ruang Sebaran Objek dan Fasilitas Penunjang Wisata Berbasis Sistem Informasi Geografis di Kawasan Taman Nasional Bali Barat
}

\author{
Titan Octalia Barnad ${ }^{1}$, I Gusti Agung Ayu Rai Asmiwyati1 ${ }^{1 *}$, Ni Nyoman Ari Mayadewi²
}

1. Prodi Arsitektur Lanskap, Fakultas Pertanian, Universitas Udayana, Jl. P.B. Sudirman, Denpasar, Indonesia

2. Prodi Agroekoteknologi, Fakultas Pertanian, Universitas Udayana, Jl. P.B. Sudirman, Denpasar, Indonesia

*E-mail: asmiwyati@unud.ac.id

\begin{abstract}
The Spatial Distribution Patterns of Tourism and Supporting Facility Based On Geographic Information Systems In The West Bali National Park. The West Bali National Park area is a nature protection area that has a conservation function as well as educational tourism. This has boosted enthusiasm for tourist visits, followed by a rapidly increasing development of tourism support facilities in the TNBB area and its buffer villages. However, these developments have not been properly recorded and mapped, so a mapping process is necessary. The method used in this research was a survey with data collection techniques including direct observation, interviews, and literature study. The stages of this research were the identification of tourism support facilities and objects according to the tourism support facilities criteria indicators, analysis, and synthesis. The GIS analysis process used the nearest neighbor analysis approach to study the distribution patterns formed from the distribution of tourism support facilities in the TNBB area. This analysis process produced recommendations for the development of tourism support facilities based on accessibility factors, distance, and the agglomeration theory approach can be used as a basis for regional development, especially in the elements of facilities and infrastructure in the TNBB area.
\end{abstract}

Keywords: distribution patterns, mapping, regional development, GIS

\section{Pendahuluan}

Taman Nasional Bali Barat (TNBB) terletak pada ujung barat Pulau Bali dan berada pada gerbang masuk menuju Pulau Bali yang terdiri dari wilayah perairan maupun daratan. TNBB dalam menjalankan tiga fungsi utama yaitu perlindungan, pengawetan, dan pemanfaatan dibantu oleh enam desa penyangga yang tiga diantaranya aktif membantu TNBB dalam menjalankan semua program konservasi maupun pariwisata. Keterlibatan masyarakat desa penyangga dalam bidang pariwisata diperlukan karena menurut Internationale Tourismus Borse Berlin pada tahun 2018, TNBB ditetapkan sebagai salah satu dari 100 destinasi terbaik seAsia Pasifik. Hal ini membuat minat wisata menuju TNBB menjadi sangat besar ditinjau dari data kunjungan wisatawan menuju TNBB setiap tahunnya dengan rata-rata peningkatan sebanyak 1200 wisatawan tiap tahunnya, dan hal ini menyebabkan berkembangnya fasilitas dan perkembangan fasilitas tidak terarah dan memerlukan upaya penataan

Penelitian ini bertujuan mengidentifikasi sebaran fasilitas penunjang wisata yang terdapat pada TNBB dan desa penyangga kawasan TNBB, serta membuat rekomendasi peta model wilayah pengembangan fasilitas penunjang wisata berdasarkan jangkauannya terhadap objek wisata. Penelitian ini dimulai dari proses pencarian data lapangan, berupa sebaran titik koordinat fasilitas penunjang wisata dan objek wisata yang berada di kawasan TNBB menggunakan GPS serta mengidentifikasikan sebaran fasilitas yang ada kedalam kelompok fasilitas penunjang wisata berdasarkan Peraturan Pemerintah Republik Indonesia No 50 Tahun 2011 Tentang Rencana Induk Pembangunan Kepariwisataan Nasional Tahun 2010 2025. Proses identifikasi penelitian ini dilakukan dengan overlay semua peta dan data spasial yang didapat. Hasil dari proses overlay kemudian diolah dengan metode analisis tetangga terdekat. Proses analisis ini menghasilkan nilai rasio yang dapat dijadikan dasar untuk menentukan pola sebaran dan data untuk membuat peta rekomendasi wilayah pengembangan fasilitas penunjang wisata kawasan TNBB. 


\section{Metode Penelitian}

Penelitian ini dilakukan pada wilayah kawasan TNBB dan desa penyangga di sekitarnya antara lain, Sumber Klampok, Gilimanuk, Ekasari, Blimbingsari, Pejarakan, dan Melaya. Adapun area penelitian yang berada di zona pemanfaatan dari kawasan TNBB dan desa penyangga sekitarnya memiliki luas area studi 10.387,56 ha (Gambar 1)

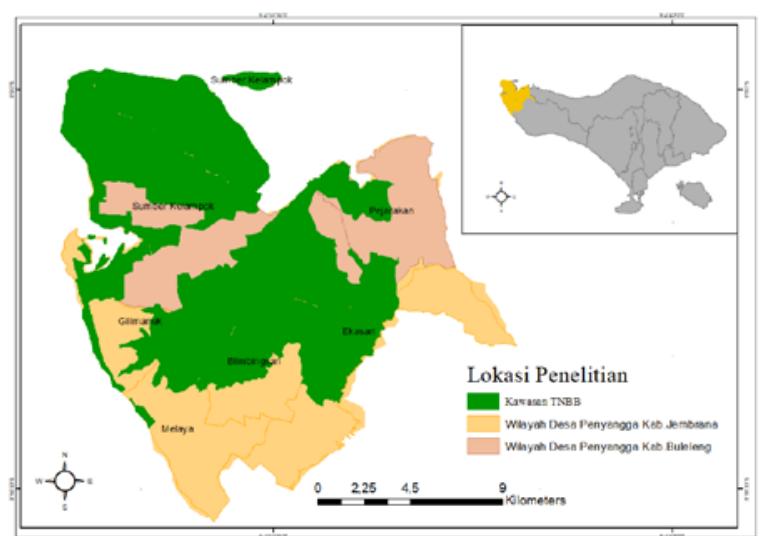

Gambar 1. Lokasi Penelitian di Kawasan TNBB (Google Earth, 2019)

\subsection{Alat dan Bahan}

Alat yang digunakan pada penelitian ini adalah kamera digital, alat tulis, GPS yang digunakan saat melakukan observasi langsung di lokasi penelitian, serta komputer yang didukung oleh perangkat lunak berupa Microsoft Office Word, Microsoft Office Excel, DNRGPS Aplication, Google Earth, ArcGIS, dan Photoshop.

\subsection{Metode Analisis}

Metode yang digunakan dalam penelitian ini adalah survei, dengan teknik pengambilan data antara lain pengamatan langsung, wawancara dan studi pustaka. Jenis data untuk memenuhi tujuan penelitian ini terinci pada Tabel 1.

Tabel 1. Jenis, Sumber, Bentuk Data yang Dibutuhkan

\begin{tabular}{|c|c|c|c|}
\hline No & Jenis Data & Sumber & Bentuk Data \\
\hline A. & Data Fisik & & \\
\hline 1 & $\begin{array}{l}\text { Titik koordinat objek wisata } \\
\text { dan fasilitas penunjang wisata }\end{array}$ & Observasi Langsung (GPS) & Data Spasial \\
\hline 2 & $\begin{array}{l}\text { Peta tata guna lahan zona } \\
\text { pemanfaatan TNBB }\end{array}$ & TNBB & Peta \\
\hline 3 & $\begin{array}{l}\text { Peta administrasi Kabupaten Jembrana } \\
\text { dan Kabupaten Buleleng }\end{array}$ & BAPPEDA & Peta \\
\hline 4 & Peta sistem jaringan jalan Kawsan TNBB & BAPPEDA & Dokumen RTRW \\
\hline 5 & Peta sebaran objek wisata di TNBB & TNBB & Peta \\
\hline 6 & Peta wilayah kerja resort TNBB & TNBB & Peta \\
\hline B & Data Wisata & & \\
\hline 1 & Jenis objek wisata dan aktivitas wisata & Observasi & Deskriptif \\
\hline 2 & $\begin{array}{l}\text { Jenis fasilitas penunjang wisata dan } \\
\text { fungsinya }\end{array}$ & Observasi & Deskriptif \\
\hline 3 & $\begin{array}{l}\text { Data kepuasan pengunjung } \\
\text { TNBB pada kawasan TNBB }\end{array}$ & $\begin{array}{l}\text { Observasi } \\
\text { (kuisioner) }\end{array}$ & Deskriptif \\
\hline
\end{tabular}

Tahapan metode penelitian yang digunakan adalah diawali dengan inventarisasi dan identifikasi, kemudian analisis dan sintesis. Inventarisasi dan identifikasi yang dilakukan berupa observasi langsung ke lapangan dan wawancara untuk mengetahui antusiasme pengunjung sebagai data pendukung terjadinya kecenderungan untuk melakukan repetisi kunjungan yang mempengaruhi pengembangan wilayah khususnya fasilitas penunjang wisata pada kawasan TNBB. Proses identifikasi objek wisata dan fasilitas penunjang 
wisata mengikuti kaidah yang tercantum pada (Agusbushro, 2015), terdapat 16 kriteria fasilitas yang dijabarkan pada Tabel 2.

Tabel 2. Kriteria Fasilitas yang Diidentifikasi

\begin{tabular}{|c|c|c|c|}
\hline No & Jenis Fasilitas & Kriteria Fasilitas & Tempat \\
\hline 1 & $\begin{array}{l}\text { Fasilitas Penunjang } \\
\text { Ekonomi dan Bisnis }\end{array}$ & $\begin{array}{l}\text { Fasilitas Keuangan } \\
\text { Fasilitas Bisnis }\end{array}$ & $\begin{array}{l}\text { ATM, Money Changer, Bank } \\
\text { Warung Internet, Supermarket, Warung Telekomunikasi, } \\
\text { Sarana Penitipan dan Penyimpanan barang }\end{array}$ \\
\hline 2 & $\begin{array}{l}\text { Fasilitas Penunjang } \\
\text { Kesehatan dan } \\
\text { Sanitasi }\end{array}$ & $\begin{array}{l}\text { Fasilitas Kesehatan } \\
\text { Fasilitas Sanitasi } \\
\text { Fasilitas Berkebutuhan } \\
\text { khusus }\end{array}$ & $\begin{array}{l}\text { Poliklinik } 24 \text { jam, Rumah Sakit,Apotek, Fasilitas Medis } \\
\text { lainnya } \\
\text { Toilet umum, Jasa Binatu, Tempat Pembuangan Sampah } \\
\text { Umum } \\
\text { Panti Jompo, Panti Asuhan, Panti Sosial }\end{array}$ \\
\hline 3 & $\begin{array}{l}\text { Fasilitas Penunjang } \\
\text { Keamanan }\end{array}$ & $\begin{array}{l}\text { Fasilitas Keamanan } \\
\text { Polisi dan Satgas }\end{array}$ & $\begin{array}{l}\text { Kantor Pemadam Kebakaran, Fasilitas Tanggap Bencana } \\
\text { Kantor Polisi }\end{array}$ \\
\hline 4 & $\begin{array}{l}\text { Fasilitas Penunjang } \\
\text { Transportasi }\end{array}$ & $\begin{array}{l}\text { Area pemberhentian } \\
\text { transportasi umum }\end{array}$ & Terminal, Stasiun, Pelabuhan/dermaga, Bandara \\
\hline 5 & $\begin{array}{l}\text { Fasilitas } \\
\text { Kenyamanan } \\
\text { Pariwisata }\end{array}$ & $\begin{array}{l}\text { Fasilitas Rekreasi } \\
\text { Fasilitas Lahan Parkir } \\
\text { Fasilitas Ibadah } \\
\text { Akomodasi } \\
\text { Rumah Makan } \\
\text { Informasi Pelayanan } \\
\text { Wisata } \\
\text { Toko Cinderamata }\end{array}$ & $\begin{array}{l}\text { Taman Bermain Anak, Tempat Olahraga, Public Space } \\
\text { Lahan Parkir Umum } \\
\text { Masjid, Pura, Gereja, Wihara } \\
\text { Hotel, Guest house, Villa } \\
\text { Restauran, Rumah Pemesanan Makanan } \\
\text { Pelayanan Imigrasi, Pusat Informasi Wisata } \\
\text { Toko Cinderamata dan Souvenir }\end{array}$ \\
\hline
\end{tabular}

Proses analisis data menggunakan dua cara antara lain analisis kuantitatif, serta analisis spasial menggunakan analisis tetangga terdekat. Proses analisis menggunakan analisis tetangga terdekat diproses oleh Arcgis dengan rumus dasar yang dapat dilihat pada Gambar 2.

\section{Rumus Analisis Tetangga Terdekat:}

$$
T=\frac{\mathrm{Ju}}{\mathrm{Jh}}
$$

$T=$ Indeks penyebaran tetangga terdekat

$\mathrm{Ju}=\mathrm{Jarak}$ rata - rata yang diukur antara satu titik dengan titik tetangganya yang terdekat

$\mathrm{Jh}=$ Jarak rata - rata yang diperoleh bilamana semua titik mempunyai pola random $\left(\frac{1}{2 \sqrt{\mathrm{p}}}\right)$

$\mathrm{P}=$ Kepadatan titik dalam tiap kilometer persegi yaitu jumlah titik $(\mathrm{N})$ dibagi luas wilayah (A)
Bentuk Pola Sebaran Sesuai Nilai N:

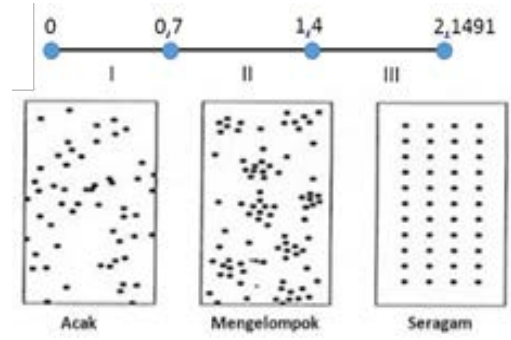

Gambar 2. Rumus Analisis Tetangga Terdekat

Selain menggunakan analisis tetangga terdekat, digunakan juga rumus isoline yang dijabarkan oleh Riyadi (2003, dalam Muta'ali, 2015) untuk menentukan jangkauan maksimum dan area strategis pengembangan fasilitas penunjang wisata terhadap objek wisata pada kawasan TNBB dan desa penyangga disektarnya. Adapun rumus tersebut adalah:

$$
J p r=M t x(J t / t)
$$

Keterangan:

$\mathrm{Jpr}=$ Daya jangkau pelayanan riil maksimum

$\mathrm{Jt}=$ Jarak tempuh sebenarnya

$\mathrm{T}=$ Waktu tempuh sebenarnya

Mt = Asumsi Waktu tempuh 


\section{Hasil dan Pembahasan}

\subsection{Gambaran Umum}

TNBB berasal dari kawasan hutan suaka margasatwa dengan beberapa jenis satwa dan flora yang dilindungi. TNBB terdiri atas dua tipe ekosistem: darat/hutan dan perairan laut. Kawasan TNBB selain bertujuan konservasi, juga pemanfaatan wisata alam dan perikanan tangkap di laut sebagai sumber mata pencaharian masyarakat sekitarnya. TNBB dikelola oleh pemerintah pusat melalui Unit Pengelola Teknis Balai Taman Nasional. Kawasan TNBB memiliki enam desa penyangga, namun terdata tiga desa yang turut aktif melakukan kegiatan pengelolaan wilayah konservasi dan wisata bersama dengan Bali Taman Nasional, antara lain Sumberklampok, Blimbingsari, dan Gilimanuk.

\subsection{Aspek Biofisik}

\subsubsection{Kondisi Geografis, Flora Fauna, dan Batas Administrasi}

TNBB secara geografis terletak diantara 8०05'30"LS sampai 8'17'20"LS dan $114^{\circ} 26^{\prime} 00^{\prime \prime} B T$ sampai $114^{\circ} 56^{\prime} 30^{\prime \prime} B T$ dengan hamparan mulai laut pesisir hingga ke pegunungan. TNBB berada pada dua kabupaten yaitu Kabupaten Buleleng dan Kabupaten Jembrana. Keadaan topografinya landai hingga berbukit, dengan ketinggian tempat bervariasi dari 0 - 698 mdpl. Luas TNBB adalah 19.026,97 ha dengan sebaran tanah secara umum memiliki empat jenis tanah yang tersebar di berbagai wilayahnya antara lain alluvial coklat kelabu, alluvial hidrophic, mediteran coklat, dan latosol. TNBB memiliki keanekaragaman hayati yang terdiri dari beberapa tipe ekosistem yaitu hutan mangrove, hutan pantai, hutan musim, hutan hujan dataran rendah (evergreen) dan sabana dengan jumlah flora dilindungi sebanyak 14 jenis dan fauna sebanyak 10 jenis.

Kawasan TNBB beririsan langsung dengan desa penyangganya seperti yang terlihat pada Gambar 3. Pengembangan sarana prasarana maupun fasilitas berupa pembangunan wisata dan fasilitas penunjangnya berdasarkan PP No.50 Tahun 2011, pasal 9 bahwa luas areal yang diizinkan untuk dibangun sarana wisata alam paling banyak 10\% (sepuluh persen) dari luas areal yang ditetapkan dalam izin.
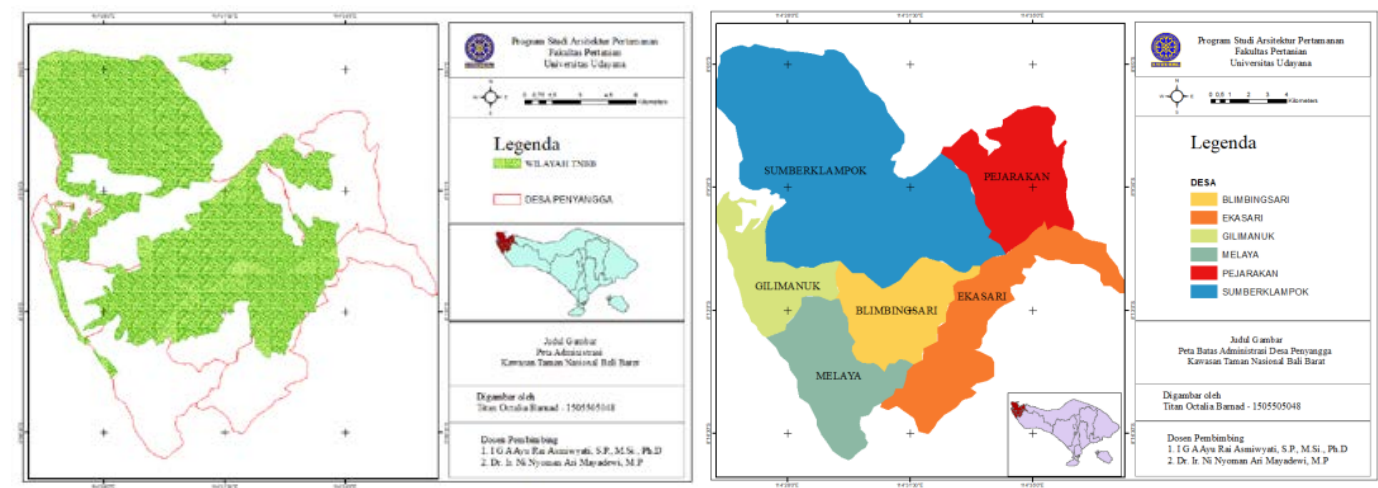

Gambar 3. Peta Administrasi Wilayah TNBB dan Desa Penyangga

\subsection{Identifikasi Aksesibilitas dan Sirkulasi}

Jarak tempuh menuju pusat kawasan TNBB melalui jalur darat dengan menggunakan kendaraan roda empat maupun roda dua ialah $90 \mathrm{~km}$ dari Kabupaten Singaraja dan $135 \mathrm{~km}$ dari Kota Denpasar dengan waktu tempuh tiga sampai empat jam. Pada area sekitar Kawasan TNBB teridentifikasi tiga jenis jalan antara lain: jalan kolektor berupa jalan nasional, jalan lokal yang berupa jalan kabupaten dan kota, dan jalan lingkungan yang menjadi jalan cabang penghubung antar pemukiman, desa dengan jalan utama, serta jalan khusus yang berupa jalan setapak yang berada di dalam zona rimba kawasan TNBB. Data jalan nasional yang terbentang di sepanjang TNBB dirinci pada Tabel 3. Adapun letak jalan, panjang jalan, dan juga jenis jalan yang ada dapat dilihat pada peta aksesibilitas kawasan TNBB yang dapat dilihat pada Gambar 4 
Tabel 3. Jaringan Jalan Nasional pada Kawasan TNBB

\begin{tabular}{lllll}
\hline No & Nama Jalan & Panjang (km) & Status & Jenis \\
\hline $\mathbf{1}$ & Gilimanuk - Cekik & 3,04 & Jalan Nasional & Jalan Kolektor \\
$\mathbf{2}$ & Cekik - Negara & 27,24 & Jalan Nasional & Jalan Kolektor \\
$\mathbf{3}$ & Cekik - Seririt & 62,91 & Jalan Nasional & Jalan Kolektor \\
\hline
\end{tabular}

Sumber: Dinas Pekerjaan Umum dan Penataan Ruang Provinsi Bali

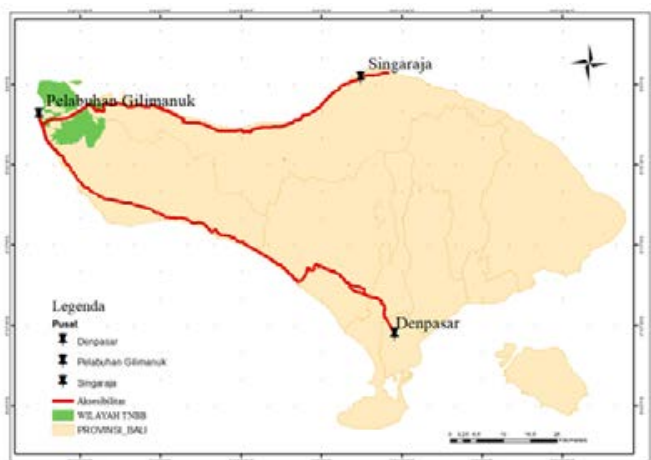

Gambar 4. Peta Jaringan Jalan Area Sekitar Kawasan TNBB

\subsection{Identifikasi Objek Wisata}

Sebaran titik objek wisata yang berada pada kawasan TNBB berjumlah 11 titik yang masing-masing berada pada kawasan TNBB wilayah Seksi Pengelolaan Taman Nasional (SPTN) I, II, III, dan desa penyangga. Jenis objek wisata dan letaknya dapat dilihat pada Gambar 5.

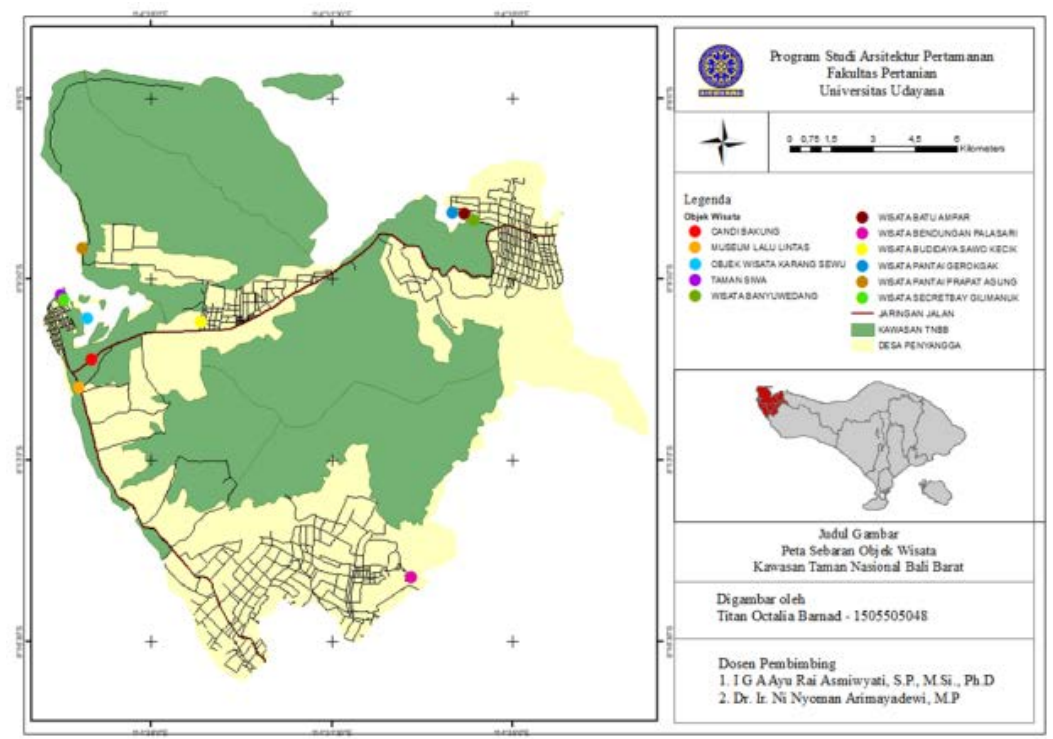

Gambar 5. Peta Sebaran Titik Objek Wisata Kawasan TNBB

Persebaran titik objek wisata yang telah ditampilkan kemudian diolah dengan menggunakan Analysist Spasial Tools dengan fungsi analisis tetangga terdekat. Hasil dari pengolahan spasial tersebut menghasilkan nilai rasio sebesar 0,05402. Rasio tersebut mengidentifikasikan bahwa pola sebaran yang terbentuk dari sebaran titik objek wisata di Kawasan TNBB adalah clustering. Hal ini dapat dilihat dari nilai $p$ value 0,000 yang menggambarkan analisis bernilai signifikan sempurna, serta nilai $z$-score negatif yang menggambarkan probabilitas atau prediksi distribusi titik berkelompok. Berikut ini disajikan hasil dari proses analisis tetangga terdekat pada Gambar 6. 


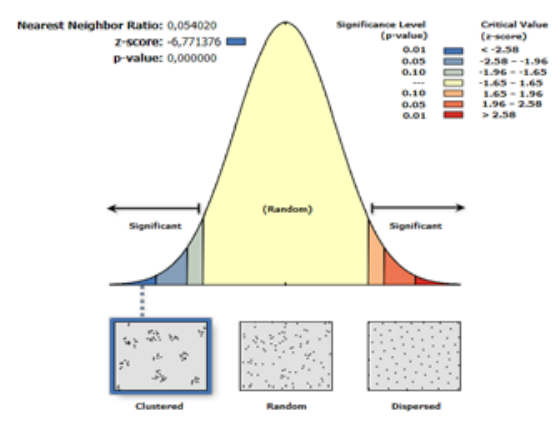

Gambar 6. Hasil dari Proses Analisis Tetangga Terdekat pada Sebaran Objek Wisata

\subsection{Identifikasi Fasilitas Penunjang Wisata}

TNBB yang berfungsi sebagai area perlindungan memiliki batasan untuk pengembangan wilayahnya. Oleh karena itu, berbagai fasilitas pendukung berupa sarana prasarana banyak terbangun bukan pada area perlindungan taman nasional melainkan pada wilayah desa penyangga dan zona pemanfaatanTNBB dengan syarat memiliki izin usaha penyediaan sarana wisata alam. Sebaran fasilitas penunjang wisata yang memiliki 113 titik dapat dilihat pada peta sebaran yang terdapat di Gambar 7.

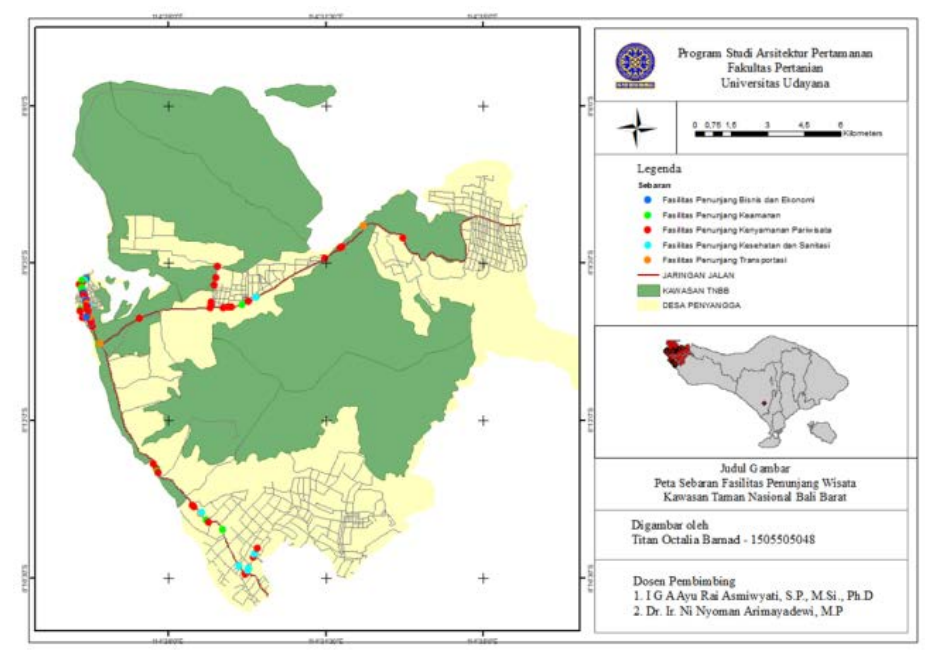

Gambar 7. Peta Sebaran Titik Fasilitas Penunjang Wisata Kawasan TNBB

Berdasarkan gambar diatas, dapat diidentifikasikan jumlah titik yang ada ke dalam kelompok fasilitas. Berikut disajikan data jumlah sarana fasilitas pendukung wisata yang tersebar di sekitar kawasan TNBB yang telah dikelompokan menjadi lima kelompok dengan uraian sebagai berikut :

Tabel 4. Jumlah Persebaran Fasilitas di Kawasan TNBB dan sekitarnya

\begin{tabular}{lll}
\hline No & Kelompok Fasilitas & Total \\
\hline $\mathbf{1}$ & Fasilitas penunjang keamanan & 13 titik \\
$\mathbf{2}$ & Fasilitas penunjang ekonomi dan bisnis & 14 titik \\
$\mathbf{3}$ & Fasilitas penunjang kesehatan dan sanitasi & 15 titik \\
$\mathbf{4}$ & Fasilitas penunjang transportasi & 11 titik \\
$\mathbf{5}$ & Fasilitas penunjang kenyamanan pariwisata & 60 titik \\
\hline
\end{tabular}

Pola sebaran yang dihasilkan dari lima bidang fasilitas penunjang wisata Kawasan TNBB yang telah melalui proses identifikasi dan analisis ialah pola sebaran clustering (berkelompok). Nilai rasio yang didapatkan dari total seluruh sebaran bidang fasilitas penunjang wisata setelah dilakukan proses analisis tetangga terdekat dapat dilihat pada Tabel 5 . 
Tabel 5. Proses penghitungan analisis tetangga terdekat

\begin{tabular}{|c|c|c|c|c|c|c|c|c|}
\hline \multirow[b]{2}{*}{ Jenis Fasilitas } & \multirow[b]{2}{*}{$\mathrm{n}$} & \multirow[b]{2}{*}{ A (luas) } & \multirow[b]{2}{*}{ Ejarak } & $\mathbf{P}$ & Ju & $\mathrm{Jh}$ & \multirow[b]{2}{*}{$\mathrm{N}$ ratio } & \multirow[b]{2}{*}{$\begin{array}{l}\text { Pola } \\
\text { Sebaran }\end{array}$} \\
\hline & & & & $\frac{n}{\mathrm{~A}}$ & $\frac{\sum \text { jarak }}{\sum \mathrm{n}}$ & $\frac{1}{2 \sqrt{P}}$ & & \\
\hline $\begin{array}{l}\text { Fasilitas Penunjang Bisnis dan } \\
\text { Eknomi }\end{array}$ & 14 & 252,3481 & 1,5094 & 0,0554 & 0,1078 & 2,1244 & 0,0507 & Clustering \\
\hline Fasilitas Penunjang Keamanan & 13 & 252,3481 & 13,4179 & 0,0515 & 1,0321 & 2,2036 & 0,4683 & Clustering \\
\hline $\begin{array}{l}\text { Fasilitas Penunjang Kesehatan } \\
\text { dan Sanitasi }\end{array}$ & 15 & 252,3481 & 11,8816 & 0,0594 & 0,7921 & 2,0517 & 0,386 & Clustering \\
\hline Fasilitas Penunjang Transportasi & 11 & 252,3481 & 21,7907 & 0,0435 & 1,9809 & 2,3975 & 0,8262 & Menyebar \\
\hline $\begin{array}{l}\text { Fasilitas Penunjang } \\
\text { Kenyamanan }\end{array}$ & 60 & 252,3481 & 12,2989 & 0,2377 & 0,2049 & 1,0256 & 0,1989 & Clustering \\
\hline
\end{tabular}

\subsection{Rekomendasi Wilayah Pengembangan Fasilitas Penunjang Wisata}

Pada peta tersebut dapat terlihat bahwa fasilitas penunjang wisata membentuk cluster yang berkembang di beberapa titik. Titik cluster terdapat pada Kelurahan Gilimanuk, pusat Kecamatan Melaya, persimpangan antara Desa Blimbingsari dengan Kelurahan Gilimanuk, pada wilayah pemukiman Desa Sumberklampok yang berdekatan dengan Objek Wisata Budidaya Sawo Kecik.

Pada peta heatmap (Gambar 8), menunjukkan pola sebaran fasilitas cenderung berkelompok dengan arah pengembangan berpusat pada titik-titik dengan interaksi sosial dan ekonomi yang tinggi sesuai dengan heatmap yaitu pada Kelurahan Gilimanuk sebagai daerah aglomerasi. Sesuai data yang disampaikan, bahwa Kelurahan Gilimanuk memiliki kelengkapan pelayanan fasilitas, aksesibilitas, kepadatan penduduk, serta kegiatan ekonomi yang tinggi. Adapun titik-titik cluster yang ada, berkembang mengikuti garis koridor jalan nasional. Faktor yang mempengaruhi perkembangan wilayah pada kawasan TNBB cenderung berada pada pusat kecamatan dan pusat ekonomi yang berada pada Kelurahan Gilimanuk, sesuai dengan pendekatan teori aglomerasi ekonomi karena pada Kelurahan Gilimanuk memiliki kelengkapan pelayanan fasilitas, aksesibilitas yang baik, kepadatan penduduk paling tinggi, serta kegiatan ekonomi yang ramai.

Aglomerasi daerah membuat konsentrasi spasial dari aktivitas ekonomi di kawasan perkotaan berada pada satu titik dan dimanfaatkan oleh daerah sekitarnya karena lokasi yang berdekatan (economies of proximity) antara tempat usaha, tempat tinggal para pekerja, dan konsumen. Teori ini dikemukakan oleh Bradley, (1996 dalam Sodik, 2007) menerangkan bahwa ekonomi aglomerasi merupakan suatu bentuk dari eksternalitas positif dalam produksi yang merupakan salah satu faktor yang menyebabkan terjadinya pertumbuhan kota. Teori tersebut sesuai dengan keadaan yang terdapat pada TNBB yang memiliki asosiasi langsung dengan tiga pusat industri yang berbeda yaitu, pelabuhan, pusat kota, dan pusat pariwisata. Unsur penting yang terdapat pada Kawasan TNBB diantaranya, tersebarnya fasilitas pelayanan umum yang ada, akses berupa jalan nasional yang membentang sepanjang TNBB, serta penggunaan lahan sesuai dengan zonasi. Unsur ini selaras dengan pernyataan menurut Sholihah, (2017) bahwa perkembangan aglomerasi berdampak terhadap perubahan spasial terkait dengan penggunaan lahan, fasilitas pelayanan umum, dan aksesibilitas. Bentuk sebaran kelompok (clustering) fasilitas penunjang wisata yang berkaitan dengan aksesibilitas dapat dilihat pada Gambar 8. 


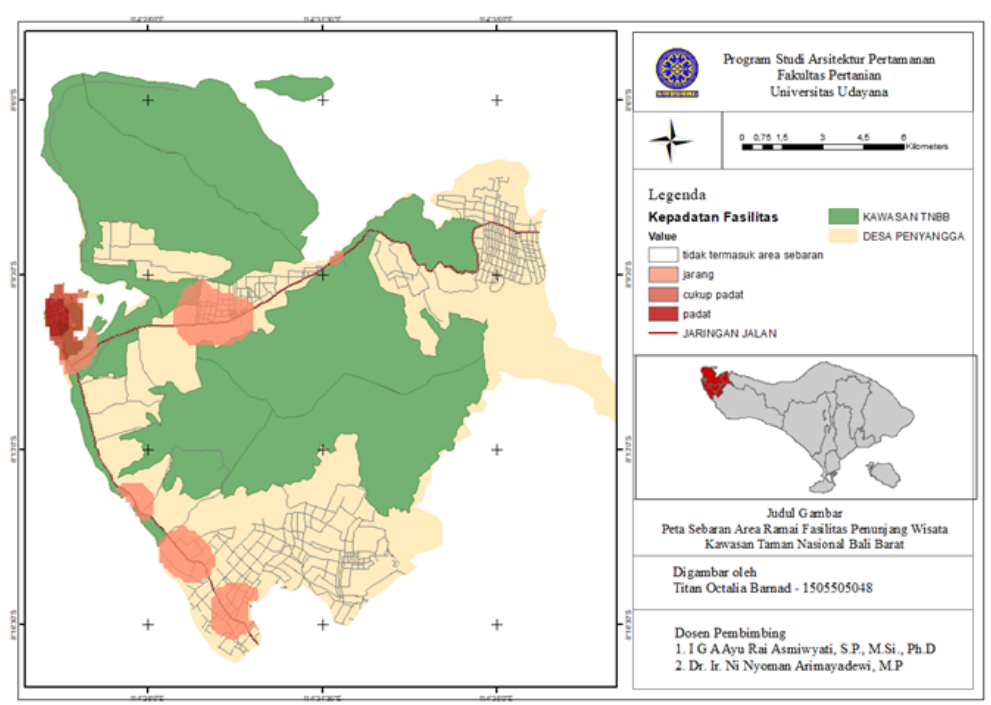

Gambar 8. Peta Area ramai (heatmap) sekitar Kawasan TNBB

Ditinjau dari analisis yang telah dilakukan, langkah selanjutnya yang dibutuhkan untuk membantu pengembangan wilayah terkait dengan fasilitas penunjang wisatanya adalah dengan membuat peta jangkauan sebaran fasilitas penunjang wisata terhadap objek wisata Kawasan TNBB. Penentuan jarak maksimum jangkauan dihitung dengan rumus daya jangkau riil maksimum pelayanan yang dikemukakan oleh Riyadi (2003 dalam Muta'ali, 2015) dengan mengalikan asumsi waktu tempuh dengan kecepatan tempuh sebenarnya. Hasil perhitungan menunjukan bahwa jarak jangkauan maksimum yaitu $16,4 \mathrm{~km}$, dengan pembagian jangkauan menjadi 6 (enam) ring sesuai dengan ketentuan satu ring jarang jangkauan minimum, dan lima ring jangkauan pelayanan yang telah disesuaikan dengan ketentuan Badan Standarisasi Nasional. Berikut disajikan peta overlay sebaran fasilitas berdasarkan jangkauannya. Pada peta tersebut diketahui bahwa setiap objek wisata memiliki satu fasilitas yang berada pada jangkauan ideal (Ring A-C), kecuali fasiltas penunjang ekonomi dan bisnis yang terpusat pada Kelurahan Gilimanuk.

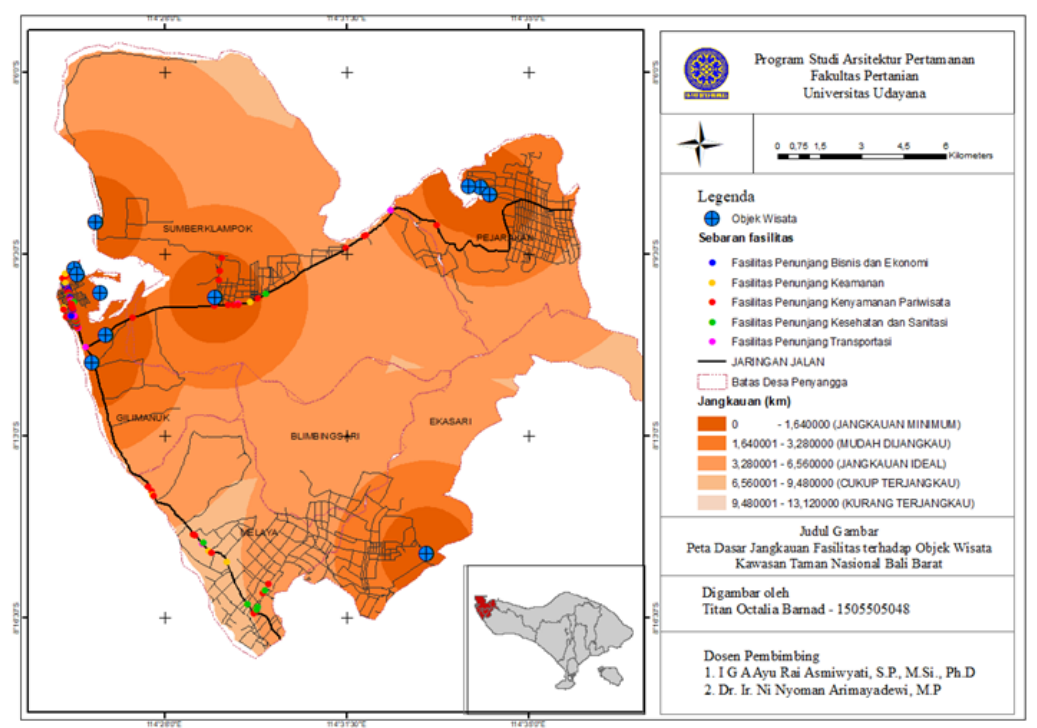

Gambar 9. Peta Dasar Jangkauan Fasilitas Penunjang Wisata terhadap Objek Wisata Kawasan TNBB

Berikut disajikan pada Gambar 10, peta konsep pengembangan fasilitas berdasarkan jangkauannya terhadap objek wisata kawasan TNBB dengan mempertimbangkan aksesibilitas dan juga area konservasi taman nasional yang tidak diperkenankan untuk dikembangkan sebagai area diluar fungsi perlindungan. 


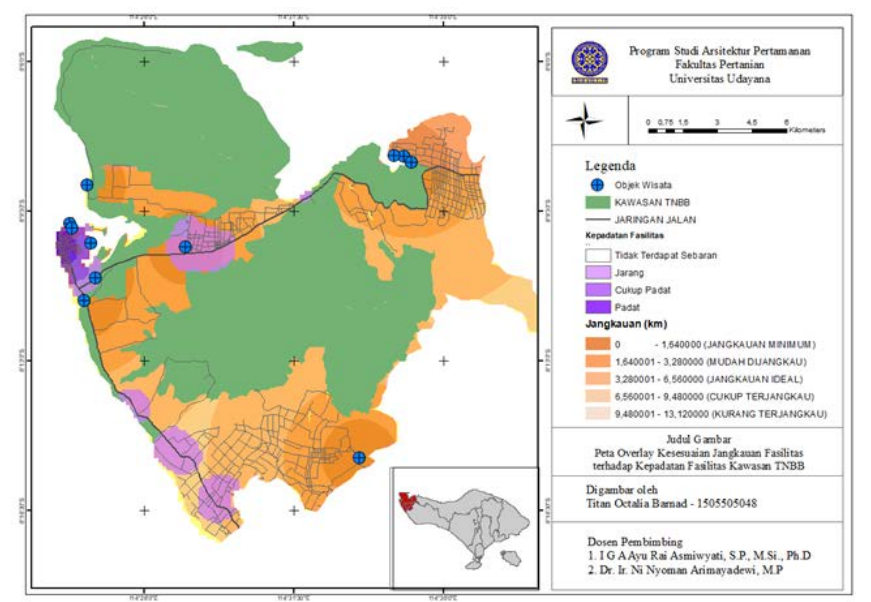

Gambar 10. Peta Kesesuaian Jangkauan Fasilitas Penunjang Wisata Terhadap Kepadatan Fasilitas

Peta konsep pengembangan pada Gambar 10 kemudian melalui proses clipping dengan wilayah konservasi TNBB karena wilayah tersebut adalah area yang tidak diperkenankan untuk dibangun dan dikembangkan. Hasil dari proses ini adalah peta rekomendasi wilayah pengembangan fasilitas penunjang wisata berdasarkan jangkauannya terhadap objek wisata Kawasan TNBB yang menghasilkan 6 (enam) wilayah rekomendasi pengembangan yang dapat dilihat pada Gambar 11.

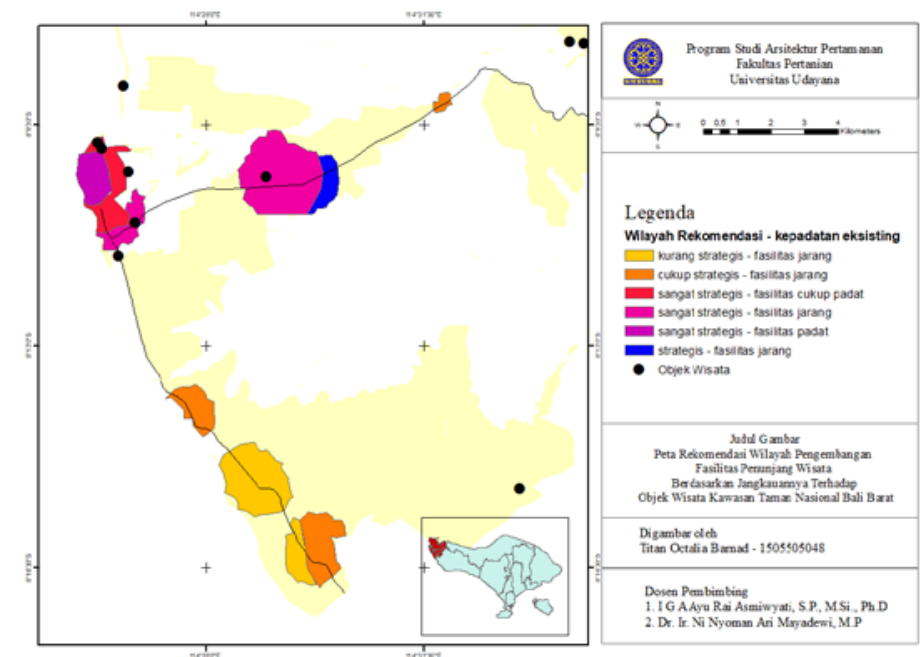

Gambar 11. Peta Rekomendasi Wilayah Pengembangan

Peta pada Gambar 11 menjelaskan bahwa rekomendasi model pengembangan dari hasil penelitian ini menghasilkan area rekomendasi dengan enam opsi wilayah pengembangan mulai dari area kurang strategis hingga sangat strategis dengan kepadatan fasilitas yang beragam mulai dari area dengan kepadatan fasilitas yang jarang hingga yang sangat padat. Opsi area rekomendasi ini ditinjau dari beberapa hal berikut yaitu, aksesibilitas, jarak jangkauan, serta kepadatan fasilitas yang ada dan membentuk suatu pola sebaran tertentu.

Namun, pengembangan wilayah untuk fasilitas penunjang wisata tidak dapat dilakukan pada zona konservasi taman nasional karena area tersebut tidak diperkenankan untuk dikembangkan. Hal ini juga menjadi penyebab arah pengembangan wilayah pelayanan fasilitas penunjang wisata cenderung berawal pada titik pusat lingkungan/kota yaitu Kelurahan Gilimanuk dan penting untuk mempertimbangkan aksesibilitas karena pola berkembangnya cluster-cluster baru cenderung mengikuti koridor jalan utama. Aspek-aspek yang ditemukan ini perlu dipertimbangkan agar model pengembangan fasilitas penunjang wisata nantinya dapat meningkatkan kenyamanan dan kepuasan bagi pengunjung, serta mempertahankan TNBB agar tetap menjadi salah satu destinasi wisata rekomendasi. 


\section{Penutup}

\subsection{Kesimpulan}

Sebaran titik objek wisata yang berada pada kawasan TNBB berjumlah 11 titik yang tersebar di dalam maupun di luar kawasan TNBB. Sebaran fasilitas penunjang wisata berjumlah 113 titik, yang membentuk pola sebaran clustering membentuk lima kelompok fasilitas penunjang wisata pada kawasan TNBB dengan kepadatan tertinggi di area Kelurahan Gilimanuk. Perkembangan tiap titik cluster berpusat pada Kelurahan Gilimanuk dengan arah pengembangan mengikuti koridor jalan utama yang terbentang sepanjang TNBB.

Adapun, rekomendasi pengembangan wilayah berdasarkan jangkauannya terbagi menjadi 6 (enam) ring jangkauan yang terdiri dari jangkauan strategis hingga tidak strategis yang dapat dijadikan sebagai dasar pengembangan wilayah dengan mempertimbangkan faktor aksesibilitas, jarak, dan aglomerasi ekonomi yang menghasilkan 6 (enam) opsi wilayah rekomendasi pengembangan.

\subsection{Saran}

Pengembangan fasilitas penunjang wisata dan potensi wisata pada kawasan TNBB masih memerlukan penelitian lanjutan terkait aspek lainnya agar dapat terlaksana. Kekurangan dari penelitian ini adalah belum terpenuhinya aspek pendukung kegiatan wisata lainnya seperti aspek ekonomi, sosial budaya masyarakat dan ekologi. Oleh karena itu diharapkan agar penelitian selanjutnya, untuk melengkapi analisis yang belum tercantum agar dapat menjadi pertimbangan awal dan data dasar untuk melakukan pengmbangan wilayah lanjutan terhadap fasilitas penunjang wisata di kawasan TNBB.

\section{Daftar Pustaka}

Agusbushro, R. 2015. Analisis Kebutuhan Prasarana dan Sarana Pariwisata di Kawasan Taman Nasional Bunaken Kecamatan Bunaken Kepulauan Kota Manado. Spasial, 2(2) :122-131.

Apriyani, D. A. 2017. Pengaruh Kualitas Layanan Terhadap Kepuasan Konsumen Hypermarket. Jurnal Administrasi Bisnis, 51(2):6-7.

Badan Standard Nasional. 2003. Tata Cara Perencanaan Lingkungan Perumahan, Bandung.

Cynthia, E.V. Wuisang, S. S. 2016. Analisis Kebutuhan Prasarana Dan Sarana Pariwisata Di Danau Uter Kecamatan Aitinyo Kabupaten Maybrat Provinsi Papua Barat. Skripsi (tidak dipublikasi) Universitas Sam Ratulangi, Manado.

Dewi, A. 2016. Aglomerasi Dan Pemanfaatan Ruang Di Kota Banda Aceh. Jurnal Ilmiah Mahasiswa, 1(2):311-320.

Muta'ali, L. 2014. Teknik Analisis Regional. Badan Penerbit Fakultas Geografi UGM, Yogyakarta.

Sholihah, Darul Amal. 2018. Dampak Perkembangan Aglomerasi Industri Gondangrejo, Karanganyar terhadap Perubahan Spasial. Jurnal Pembangunan Wilayah dan Pengembangan Partisipatif, 13(2):115-132.

Sodik, J. 2007. Aglomerasi Dan Pertumbuhan Ekonomi: Peran Karakteristik Regional Di Indonesia. Jurnal Ekonomi dan Studi Pembangunan, 8(2):117-129.

Swartawa, I. M. 2018. Pemetaan Kejadian Diare di Lingkungan Wilayah Kerja Unit Pelayanan Terpadu Kesehatan Masyarakat Gianyar II. Skripsi (tidak dipublikasi) Politeknik Kesehatan Kemenkes Denpasar.

Utama, I. R. 2014. Pengantar Industri Pariwisata. CV Budi Utama. Yogyakarta 